\title{
ASSESSMENT OF CARBON STOCK AND NUTRIENT CONTENTS IN SOILS OF NORTHERN AND EASTERN PIEDMONT PLAINS OF BANGLADESH
}

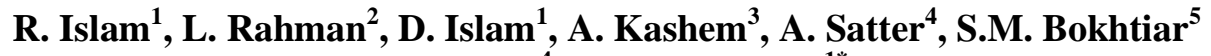 \\ B. Hossain ${ }^{4}$ and M. Rahman ${ }^{\text {* }}$ \\ ${ }^{1}$ Dept. of Soil Science, Bangabandhu Sheikh Mujibur Rahman Agricultural University \\ Gazipur 1706, Bangladesh \\ ${ }^{2}$ Soil Resource Development Institute, Dhaka 1215, Bangladesh \\ ${ }^{3}$ Sylhet Agricultural University, Sylhet, Bangladesh \\ ${ }^{4}$ Bangladesh Agricultural Research Council, Dhaka 1215, Bangladesh \\ ${ }^{5}$ SAARC Agriculture Centre, Dhaka 1215, Bangladesh
}

\begin{abstract}
Under the changing climate documentation of soil carbon and nutrients is indispensable for sustainable crop production which is scarce in the agro-ecological zone (AEZ) of Northern and Eastern Piedmont Plains in Bangladesh. Therefore, the study was conducted collecting and analyzing a total of 240 soil samples considering $0-20 \mathrm{~cm}$ soil depth from two upazilas viz. Purbadhola and Akhaura under the mentioned AEZ to quantity carbon stock and nutrient contents of soils. Organic carbon stocks in soils of Purbadhola and Akhaura upazila were 45.97 and 97.04 $\mathrm{Gg}$, respectively, while in the Northern and Eastern Piedmont Plains was $8.56 \mathrm{Tg}$. The soil $\mathrm{pH}$ was very strongly acidic to slightly acidic (4.4-5.8), organic carbon contents $(0.53-1.31 \%)$ were very low to medium, while the overall soil fertility rated as very low to medium. Balanced fertilization using organic and inorganic sources in general and liming for upland crops might improve fertility and productive capacity of soils in the study area. The study opens up avenues to find out means and ways of increasing carbon contents in soils of Northern and Eastern Piedmont Plains and might help the policy makers to debate on future global carbon trading issues.
\end{abstract}

Keywords: Agro-ecological zones, carbon contents, land types.

\section{INTRODUCTION}

Carbon is a vital element that accomplishes all bio-physico-chemical properties in soils. Organic carbon harbors microbial community, develops and maintains soil structure, regulates cation exchange capacity and nutrient dynamics in soils (Rahman,

\footnotetext{
*Corresponding author's email: mizan@bsmrau.edu.bd
} 
2014; Rahman et al., 2016). Soil has the potential to store three times more carbon than the terrestrial vegetation, which depends on soil and crop management practices (Tarnocai et al., 2009). Carbon storage in soils is affected by changes in vegetation and plant growth, removal of biomass by harvest and destruction through plowing and other land use changes. Soil $\mathrm{C}$ is further sensitive to climatic and environmental changes such as moisture availability, changing rainfall and temperature patterns, nitrogen availability and its dynamics in crop fields (von Lutzow et al., 2009). The subtropical climatic environment of Bangladesh where generally farmers apply more nitrogen fertilizers for higher crop yields. High temperature and high soil moisture coupled with the presence of high nitrogen favors faster decomposition of organic matter (Hossain et al., 2016). The global concerns about the effects of climate change have generated urgent research avenues on both soil organic and inorganic $\mathrm{C}$ stocks. It is reported that a good soil should have at least $2.5 \% \mathrm{OM}$, while it is less than $1.5 \%$, and some soils even less than $1 \%$ in Bangladesh (BARC, 2012). Depletion of soil organic carbon and its fertility has been recognized as the major cause that hindering crop production in Bangladesh. It is anticipated that because of climate change the production of different crops in Bangladesh would greatly be reduced and thus the country would be in food deficit condition. Selection of best and suitable cropping systems potential in storing and maintaining carbon in soils is necessary for sustaining soil health and also for limiting the negative effect of global warming in crop production. Soil and crop management practice like minimum or zero tillage, application of different available organic materials and composts, balanced fertilization, crop rotations etc. might have the high potential to increase carbon contents in soils. The sequestration of atmospheric $\mathrm{CO}_{2}$ in the soil and biomass reduces greenhouse effect which is indispensable to improve soil quality, increase agronomic productivity and use efficiency of different production inputs like fertilizers and water thus helps maintain or restore the capacity of soil to carry out its production and environmental functions on a sustainable basis. The Northern and Eastern Piedmont Plains of Bangladesh comprise gently sloping land at the foot of northern and eastern hills, where alluvial sediments derived from the hills have been deposited. Soils of the area are loams to clays in texture and OM content is very low to low (BARC, 2012). The area might have the potential in sequestering $\mathrm{C}$ and supplying different nutrients in soil but information is scarce. Therefore, the study was conducted to evaluate existing carbon stock and C, N, P and K contents of Northern and Eastern Piedmont Plains which might be helpful in improving soil health adopting different management practices at farmer's level.

\section{MATERIALS AND METHODS}

\section{Study area}

The study was conducted in two upazilas (Purbadhala and Akhaura) and three mouzas under each upazila of the agro-ecological zone Northern and Eastern Piedmont Plains (AEZ 22).The selected mouzas were Naterkona, Khatoari and 
Meghshimul from Purbadhala, while Basudebpur, Noapara and Anandapur from Akhaura.

\section{Cropping patterns in the study area}

The major cropping patterns under four different land types recognized in Purbadhala and Akhaura upazila were shown in the Table 1.

Table 1. Major cropping patterns in Purbadhala and Akhaura upazila under the Northern and Eastern Piedmont Plains (AEZ 22)

\begin{tabular}{ll}
\hline \multicolumn{1}{c|}{ Land type } & \multicolumn{1}{c}{ Cropping patterns } \\
\hline High land & Boro rice-Fallow-T. Aman rice \\
Medium high land & Boro rice-Fallow-T. Aman rice \\
Medium low land & Boro rice-Fallow-Fallow \\
Low land & Boro rice-Fallow-Fallow \\
\hline
\end{tabular}

\section{Sampling protocol}

Soil samples were collected during January to February 2011 based on land types and soil depths. A total of 240 soil samples were collected from Purbadhala and Akhaura upazila of the AEZ 22 considering ten sampling spots per mouza, four samples per spot comprising 4 soil depths $(0-5,5-10,10-15$ and 15-20 cm). Samples collected were analyzed for organic carbon and other nutrients.

\section{Study parameters and methods of analysis of soil samples}

Soil bulk density was determined by core sampler method (Blake and Hartge, 1986). After calculating the soil bulk density collected soil samples were analyzed in the chemistry laboratory, Department of Soil Science, Bangabandhu Sheikh Mujibur Rahman Agricultural University, Gazipur, Bangladesh for organic carbon and other nutrients. Soil $\mathrm{pH}$ was determined by Glass Electrode $\mathrm{pH}$ Meter method with soil water ratio 1:2.5 (McLean, 1982), organic matter by Wet Oxidation method, total $\mathrm{N}$ by Kjeldhal systems (Bremner and Mulvaney, 1982), available P by Olsen's method (Olsen and Sommers, 1982), and K by Ammonium acetate extraction method (Barker and Surh, 1982).

\section{Carbon stock calculation}

The carbon stock in soils of AEZ 22 was calculated using the equation 1, while the total carbon stock was calculated using equation 2 .

Carbon stock $\left(\mathrm{t} \mathrm{ha}^{-1}\right)=$ carbon concentration $(\%) \times$ bulk density $\left(\mathrm{g} \mathrm{cm}^{-3}\right) \times$ depth $(\mathrm{cm})$ ---- (1)

Total carbon stock $(\mathrm{t})=$ Carbon stock $\left(\mathrm{t} \mathrm{ha}^{-1}\right) \mathrm{x}$ Area $(\mathrm{ha})$

The area coverage of different land types of the AEZ were collected from fertilizer recommendation guide (BARC, 2012). 


\section{RESULTS AND DISCUSSION}

\section{Soil physical and chemical properties in different mouzas of Purbadhola upazila}

The physical and chemical properties of three selected mouzas of Purbhadhala upazila under the Northern and Eastern Piedmont Plains were studied. The land types and physico-chemical properties of Natrokona mouza were presented in Table 2. Three land types were observed in selected mouzas viz. medium high, medium low and low. There were two main cropping patterns observed in Naterkona mouza which were boro rice-fallow-T. aman rice in medium high land and boro rice-fallow-fallow in medium low and low land. The bulk density in medium high land was found 1.42 $\mathrm{g} \mathrm{c.c.}^{-1}$, whereas it was $1.31 \mathrm{~g} \mathrm{c.c.}^{-1}$ in medium low land and $1.09 \mathrm{~g} \mathrm{c.c.}^{-1}$ in low land. The lowest bulk density was found in low lands. It might be due to higher moisture content and flocculent soft layer in the top soils of low land, which contributed to less dry mass compared to medium low and medium high lands. The $\mathrm{pH}$ was found strongly acidic in all three types of land. Organic carbon status both in medium high and medium low lands were observed low as these values were 0.53 and 0.66 , respectively which corresponds to organic matter of $0.91 \%$ and $1.14 \%$, respectively. Whereas comparatively higher organic carbon $(1.31 \%)$ was recorded in low lands, which is medium as per fertility ranking (BARC, 2012). Because of the low land is saucer shaped, which receive runoff materials and organic constituents and thus upon time it becomes enriched with organic matter. However, an important finding is that even though soil organic carbon content is high but because of lower soil bulk density the resultant carbon stock is low in the low land. The nitrogen contents in all types of lands were found low possibly high rates of mineralization of soil organic matter and subsequent leaching loss of nitrate nitrogen and volatilization of ammonia under prevailing tropical and sub-tropical climatic conditions. Nitrogen contents in soils of Naterkona mouza were varied from 0.10 to $0.14 \%$. Phosphorus contents in all forms and types of lands were observed low. The potassium contents in all types of lands ranged from 0.16 to $0.17 \mathrm{c}-\mathrm{mol}(+) \mathrm{kg}^{-1}$. According to BARC (2012) such potassium level in soils are rated as low for upland crops and medium for wetland rice crop.

Table 2. Nutrient contents in soils of Naterkona mouza of Purbadhola upazila

\begin{tabular}{|c|c|c|c|c|c|c|c|c|}
\hline Land type & $\begin{array}{l}\text { Soil } \\
\text { series }\end{array}$ & Cropping pattern & $\begin{array}{c}\text { BD } \\
\left(\text { g c.c. }^{-1}\right)\end{array}$ & $\begin{array}{l}\mathrm{OC} \\
(\%)\end{array}$ & $\mathrm{pH}$ & $\begin{array}{l}\mathrm{N} \\
(\%)\end{array}$ & $\begin{array}{c}P \\
\left(\mu \mathrm{g} \mathrm{g}^{-1}\right)\end{array}$ & $\begin{array}{c}\mathrm{K} \\
\left(\mathrm{c}-\mathrm{mol}(+) \mathrm{kg}^{-1}\right)\end{array}$ \\
\hline MHL & $\mathrm{K}$ & $\begin{array}{r}\text { Boro rice } \\
\text { ama }\end{array}$ & 15 & 0.53 & & 03 & $3.00=$ & 0.01 \\
\hline MLL & Sushong & Boro rice-fallov & $1.31 \pm$ & 0.66 & 4.6 & $0.10=$ & $3.10 \pm$ & $0.17 \pm 0.00$ \\
\hline LL & Sushong & Boro rice-fallow-fallow & $1.09 \pm 0.00$ & 1.31 & $5.0-5.2$ & $0.14 \pm 0.00$ & $3.14 \pm 0.00$ & $0.17 \pm 0.00$ \\
\hline
\end{tabular}

Table 3 denotes the land types and physico-chemical properties of Khatuary mouza of Purbhadhala upazila. The major land form in Khatuary mouza was observed bill 
and the land types were medium high and medium low. Two major cropping patterns were identified in the Khatuary mouza and these were boro rice-fallow-T. aman rice in medium high land and boro rice-fallow-fallow in medium low land. In medium high land the soil bulk density was $1.45 \mathrm{~g} \mathrm{c.c.}^{-1}$, while in the low land the value was $1.34 \mathrm{~g} \mathrm{c.c.}^{-1}$. The soil organic matter content was $0.73 \%$ in medium high land and $0.57 \%$ in the medium low land. The soil $\mathrm{pH}$ in medium high land was recorded 4.85.5 and in medium low land 4.4-5.1, which was strongly acidic in both the cases. The nitrogen content in medium high land and medium low land were 0.11 and $0.10 \%$, respectively which can be ranked as low according to the soil fertility ranking of BARC (2012). Phosphorus contents in soils were 3.57 and $4.02 \mu \mathrm{g} \mathrm{g}^{-1}$ in medium high and medium low land, respectively and rated as very low (BARC, 2012). The potassium contents in soils were $0.16-0.17 \mathrm{c}-\mathrm{mol}(+) \mathrm{kg}^{-1}$ which evaluated as low.

Table 3. Nutrient contents in soils of Khatuary mouza of Purbadhola upazila

\begin{tabular}{c|c|c|c|c|c|c|c|c}
\hline Land type & $\begin{array}{c}\text { Soil } \\
\text { series }\end{array}$ & Cropping pattern & $\begin{array}{c}\mathrm{BD} \\
\left.\left(\mathrm{g} \mathrm{c}^{-1}\right)^{-1}\right)\end{array}$ & $\begin{array}{c}\mathrm{OC} \\
(\%)\end{array}$ & $\mathrm{pH}$ & $\begin{array}{c}\mathrm{N} \\
(\%)\end{array}$ & $\begin{array}{c}\mathrm{P} \\
\left(\mu \mathrm{g} \mathrm{g}^{-1}\right)\end{array}$ & $\begin{array}{c}\mathrm{K} \\
\left(\mathrm{c}-\mathrm{mol}^{(+)} \mathrm{kg}^{-1}\right)\end{array}$ \\
\hline MHL & Kongsho & $\begin{array}{r}\text { Boro rice-fallow- T. } \\
\text { aman rice }\end{array}$ & $1.45 \pm 0.14$ & 0.73 & $4.8-5.5$ & $0.11 \pm 0.03$ & $3.57 \pm 0.37$ & $0.10 \pm 0.03$ \\
MLL & Sushong & Boro rice-fallow-fallow & $1.34 \pm 0.22$ & 0.57 & $4.4-5.1$ & $0.10 \pm 0.02$ & $4.02 \pm 0.42$ & $0.15 \pm 0.01$ \\
\hline
\end{tabular}

In Meghshimul mouza, there were two land types recognized viz. high and medium low. The cropping patterns in highlands were boro rice-fallow- T. aman rice, while boro rice-fallow-fallow followed in the medium low land. The soil bulk densities of high and medium low lands were 1.34 and $1.23 \mathrm{~g} \mathrm{c.c.}^{-1}$, respectively. The $\mathrm{pH}$ of high land was slightly acidic in nature and strongly acidic soil was found in medium low land. In high and medium low land the organic carbon contents were 0.82 and $1.01 \%$, respectively. The status of organic matter content was low as per BARC ratings (BARC, 2012). The nitrogen content of high and medium high land was found $0.11 \%$ that was low. In high land phosphorus content was $15.08 \mu \mathrm{g} \mathrm{g}^{-1}$, which was low but in medium low land it was very low due to strongly acidic soil. In both land types the potassium content was attributed medium (Table 4).

Table 4. Nutrient contents in soils of Meghshimul mouza of Purbadhola upazila

\begin{tabular}{c|c|c|c|c|c|c|c|c}
\hline $\begin{array}{c}\text { Land } \\
\text { type }\end{array}$ & $\begin{array}{c}\text { Soil } \\
\text { series }\end{array}$ & Cropping pattern & $\begin{array}{c}\mathrm{BD} \\
\left(\mathrm{g} \mathrm{c.c.}^{-1}\right)\end{array}$ & $\begin{array}{c}\mathrm{OC} \\
(\%)\end{array}$ & $\mathrm{pH}$ & $\begin{array}{c}\mathrm{N} \\
(\%)\end{array}$ & $\begin{array}{c}\mathrm{P} \\
\left(\mu \mathrm{g} \mathrm{g}^{-1}\right)\end{array}$ & $\begin{array}{c}\mathrm{K} \\
\left(\mathrm{c}-\mathrm{mol}^{-1}(+)\right. \\
\left.\mathrm{kg}^{-1}\right)\end{array}$ \\
\hline $\mathrm{HL}$ & Sushong & $\begin{array}{c}\text { Boro rice-fallow- T. aman } \\
\text { rice }\end{array}$ & $1.34 \pm 0.16$ & 0.82 & $5.6-5.8$ & $0.11 \pm 0.03$ & $15.08 \pm 0.46$ & $0.16 \pm 0.01$ \\
MLL & Kongsho & Boro rice-fallow-fallow & $1.23 \pm 0.26$ & 1.01 & $4.8-5.2$ & $0.11 \pm 0.03$ & $3.72 \pm 0.52$ & $0.16 \pm 0.01$ \\
\hline
\end{tabular}

BD - Bulk density, OC- Organic carbon, N- Nitrogen, P- Phosphorus, K- Potassium, MHL - Medium high land, MLL - Medium low land, LL - Low land 


\section{Soil physical and chemical properties in different mouzas of Akhaura upazila}

The physical and chemical properties of three selected mouzas viz. Basudebpur, Noapara and Anandopur of Akhaura upazila under the Northern and Eastern Piedmont Plains were assessed. In Basudebpur mouza, there was one land form, which was ascribed as Pahartolir danga. The land types and soil properties were shown in Table 5. Two land types were recognized viz. high and medium high where both land types were under the Pritimpasha soil series. Farmers of this mouza practiced mainly one cropping pattern, which was boro rice-fallow- T. aman rice. The bulk density of high land was $1.34 \mathrm{~g} \mathrm{c.c.}^{-1}$, while in medium high land it was $1.33 \mathrm{~g}$ c.c. ${ }^{-1}$. The organic carbon contents in high land and medium high land were 0.83 and $0.95 \%$, respectively and rated as low according to BARC (2012). The soils of high land and medium high land were strongly acidic and slightly acidic, respectively. The nitrogen contents in high and medium high land were $0.16 \%$ and $0.15 \%$, respectively, which were low (BARC, 2012). The phosphorus contents in high and medium high

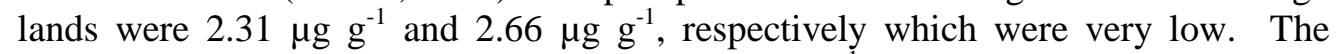
potassium content in high land was $0.12 \mathrm{c}-\mathrm{mol}(+) \mathrm{kg}^{-1}$ and in medium high land 0.13 c-mol (+) $\mathrm{kg}^{-1}$ and rated as low.

Table 5. Nutrient contents in soils of Basudebpur mouza of Akhaura upazila

\begin{tabular}{|c|c|c|c|c|c|c|c|c|}
\hline Land type & Soil series & Cropping pattern & $\begin{array}{c}\mathrm{BD} \\
\left(\text { g c.c. }^{-1}\right)\end{array}$ & $\begin{array}{l}\text { OC } \\
(\%)\end{array}$ & $\mathrm{pH}$ & $\begin{array}{l}\mathrm{N} \\
(\%)\end{array}$ & $\begin{array}{c}\mathrm{P} \\
\left(\mu \mathrm{g} \mathrm{g}^{-1}\right)\end{array}$ & $\begin{array}{c}\mathrm{K} \\
\left(\mathrm{c}-\mathrm{mol}(+) \mathrm{kg}^{-1}\right)\end{array}$ \\
\hline HL & \multicolumn{3}{|c|}{$\begin{array}{c}\text { Pritimpasha Boro rice-fallow- } 1.34 \pm 0.12 \\
\text { T. aman rice }\end{array}$} & 0.83 & \multicolumn{3}{|c|}{$4.6-5.20 .16 \pm 0.052 .31 \pm 0.43$} & $0.12 \pm 0.04$ \\
\hline MHL & Pritimpasha & $\begin{array}{l}\text { Boro rice-fallow- } \\
\text { T. aman rice }\end{array}$ & $1.33 \pm 0.13$ & 0.95 & \multicolumn{3}{|c|}{$\begin{array}{lll}5.6-5.7 & 0.15 \pm 0.03 & 2.66 \pm 0.42\end{array}$} & $0.13 \pm 0.01$ \\
\hline
\end{tabular}

The land form in the Noapara mouza was also identified as Pahartolir danga, where two different types of lands were identified viz. medium high and low (Table 6). Boro rice-fallow-T. aman rice cropping pattern was followed in medium high land and boro rice-fallow-fallow followed in low land (Table 6). Low land remains submerged several months of the year and flooding occurs within 180 to $300 \mathrm{~cm}$ during the flood season. Therefore, only boro rice crop is grown in low land as this rice is grown in the dry season when water depth reduced and sometimes land becomes dry. The bulk densities of medium high and low lands were 1.42 and $1.25 \mathrm{~g}$ c.c. ${ }^{-1}$, respectively. During collection of soil samples low lands were under water and therefore, same core contained less amount of dry soil mass in low land compared to medium high lands. Therefore, soil bulk density was lower in low lands than that of medium high lands. The organic carbon contents in both medium high and low lands were found about $1 \%$ and rated as medium. The $\mathrm{pH}$ of medium high and low land were identified slightly acidic and strongly acidic, respectively. The nitrogen content in medium high land was $0.11 \%$, while it was slightly higher $(0.15 \%)$ in lowland. 
However, as per soil fertility ranking given by BARC (2012) nitrogen status was rated low in both types of land. The phosphorus content in both types of land was found low (Table 6).

Table 6. Nutrient contents in soils of Noapara mouza of Akhaura upazila

\begin{tabular}{c|c|c|c|c|c|c|c|c}
\hline Land type & Soil series & Cropping pattern & $\begin{array}{c}\mathrm{BD} \\
\left(\mathrm{g} \mathrm{c.c.}^{-1}\right)\end{array}$ & $\begin{array}{c}\mathrm{OC} \\
(\%)\end{array}$ & $\mathrm{pH}$ & $\begin{array}{c}\mathrm{N} \\
(\%)\end{array}$ & $\begin{array}{c}\mathrm{P} \\
\left(\mu \mathrm{g} \mathrm{g}^{-1}\right)\end{array}$ & $\begin{array}{c}\mathrm{K} \\
\left(\mathrm{c}-\mathrm{mol}^{(+)} \mathrm{kg}^{-1}\right)\end{array}$ \\
\hline MHL & Pritimpasha & $\begin{array}{c}\text { Boro rice-fallow- } \\
\text { T. aman rice }\end{array}$ & $1.42 \pm 0.23$ & 1.10 & $5.5-5.8$ & $0.11 \pm 0.05$ & $2.48 \pm 0.76$ & $0.11 \pm 0.04$ \\
LL & Pritimpasha & Boro rice-fallow-fallow & $1.25 \pm 0.19$ & 1.08 & $4.5-5.2$ & $0.15 \pm 0.04$ & $2.37 \pm 0.18$ & $0.15 \pm 0.04$ \\
\hline
\end{tabular}

In Anandopur mouza, there were two different types of land found viz. medium high and medium low. Both types of lands were under the common single land form Pahartolir danga and the soil series was Pritimpasha (Table 7). Boro rice-fallow-T. aman rice cropping pattern was followed in medium high land, while it was boro rice-fallow-fallow in the medium low land. The soil bulk densities in medium high and medium low lands were 1.48 and 1.54 g c.c. $^{-1}$, respectively (Table 7).

Table 7. Nutrient contents in soils of Anandopur mouza of Akhaura upazila

\begin{tabular}{|c|c|c|c|c|c|c|c|c|}
\hline Land type & Soil series & Cropping pattern & $\begin{array}{c}\text { BD } \\
\left(\text { g c.c. }^{-1}\right)\end{array}$ & \begin{tabular}{l|}
$\mathrm{OC}$ \\
$(\%)$
\end{tabular} & $\mathrm{pH}$ & $\begin{array}{l}\mathrm{N} \\
(\%)\end{array}$ & $\begin{array}{c}P \\
\left(\mu g^{-1}\right)\end{array}$ & $\begin{array}{c}\mathrm{K} \\
\left(\mathrm{c}-\mathrm{mol}(+) \mathrm{kg}^{-1}\right)\end{array}$ \\
\hline MHL & Pritimpasha & $\begin{array}{l}\text { Boro rice-fallow- } \\
\text { T. aman rice }\end{array}$ & $1.48 \pm 0.17$ & 1.0 & $5.5-5.7$ & $0.15 \pm 0.03$ & $2.78 \pm 0.36$ & $0.14 \pm 0.01$ \\
\hline MLL & Pritimpasha & Boro rice-fallow-fallow & $1.54 \pm 0.29$ & 0.84 & $4.5-5.5$ & $0.13 \pm 0.04$ & $2.57 \pm 0.41$ & $0.14 \pm 0.01$ \\
\hline
\end{tabular}

BD - Bulk density, OC- Organic carbon, N- Nitrogen, P- Phosphorus, K- Potassium, HL - High land, MHL - Medium high land, MLL - Medium low land, LL - Low land

The organic carbon content in soils of medium high land of Anandopur mouza under Akhaura upazila was $1.0 \%$, which is rated as low. However, this was comparatively higher than that of low land, which was $0.84 \%$. The organic carbon status was low to medium in soils under both land types. In medium high land two rice crops boro rice and $\mathrm{T}$. aman rice are cultivated and thus more rice straw added to soil as crop is harvested leaving about $15-20 \mathrm{~cm}$ in the field which contributed higher organic carbon in soils under medium high land compared to medium low land. In medium high and medium low lands the soil reactions were slightly acidic and strongly acidic, respectively (Table 7). The nitrogen content was identified as low in both land types. The phosphorus contents were very low, which were $2.78 \mu \mathrm{g} \mathrm{g}^{-1}$ in medium high land and $2.57 \mu \mathrm{g} \mathrm{g}^{-1}$ in low land. The potassium content in soil was found $0.14 \mathrm{c}-\mathrm{mol}$ $(+) \mathrm{kg}^{-1}$ in both of the land types. 
The soil reaction under the Northern and Eastern Piedmont Plains was found slightly acidic to strongly acidic, which is the result of very high level of iron in the study area (SRDI, 2009). Furthermore, because of high iron contents in the study area soil inherent and applied phosphate fix with iron thereby reduces the availability of phosphorus in soils for plant uptake. The fixation of phosphorus in the acid soils makes phosphorus management difficult for crop production. However, as rice is the only crop growing in the study area, soil $\mathrm{pH}$ is not a serious concern. Rice is water loving crop and $\mathrm{pH}$ tends to increase in submerged condition. But if farmers plan to grow upland crops or vegetables then liming is needed for better crop production. Therefore, liming is recommended in the study area to raise soil $\mathrm{pH}$ and make suitable for upland crops. Maximum availability of phosphorus generally occurs in a $\mathrm{pH}$ range of 6.5 to 7.5 (BARC, 2012). The soil organic carbon increases with the raising of $\mathrm{pH}$ as soil having low $\mathrm{pH}$ retards tree growth because of nutrient deficiencies, which leads to a decline in the inputs of soil organic matter into the soil from trees compared to soils with a higher $\mathrm{pH}$ (Augusto et al., 2002; Laganiere et al., 2010). Soil organic carbon contents in the study area were found low to medium. Organic matter contents were found higher in the medium low and low land compared to high and medium high lands. However, it may differ with the location, soil and crop management practices, microclimates and many other factors. Intensive crop cultivation systems using higher rates of inorganic fertilizers favor faster degradation of organic matter in soils. The climatic condition of Bangladesh is characterized by high temperature and high rainfall which further augment decomposition of organic matter in soils. Supply of organic matter to soils also greatly reduced because of unavailability of organic materials and deliberate removal of crop residues from fields during crop harvesting.

\section{Carbon stock in soils of Purbadhola and Akhaura upazila and in the Northern and Eastern Piedmont Plains}

Four types of land viz. high, medium high, medium low and low land were observed in Purbadhola upazila where the average organic carbon accumulations in $0-20 \mathrm{~cm}$ soil layer were $25.40,16.42,18.81$ and $28.44 \mathrm{t} \mathrm{ha}^{-1}$, respectively and the carbon stocks were $0.97,0.76,19.28$ and $24.97 \mathrm{Gg}$, respectively (Table 8).The total carbon stock in Purbadhola upazila was $45.97 \mathrm{Gg}$. In Akhaura upazila there were also four land types observed viz. high, medium high, medium low and low land and the average organic carbon accumulations were $23.56,26.61,24.80$ and $30.00 \mathrm{t} \mathrm{ha}^{-1}$, respectively, where the carbon stocks were $29.00,67.24,14.63$ and $12.27 \mathrm{Gg}$, respectively (Table 9). In low land the average organic carbon content was the highest but the area was higher in medium high land so the carbon stock was the highest in medium high land. In Akhaura upazila the total land was 3649 ha and carbon stock was $97.04 \mathrm{Gg}$. In low land the average organic carbon content was the highest, but the area coverage was higher in medium low land and it is observed in both Purbadhola and Akhaura upazila. So, the carbon stock was the highest in medium low land in both the upazilas. 
Table 8. Organic carbon stocks in different mouza of Purbadhola upazila under the agro-ecological zone Northern and Eastern Piedmont Plains in Bangladesh

\begin{tabular}{|c|c|c|c|c|c|c|}
\hline \multirow[t]{2}{*}{$\begin{array}{l}\text { Land } \\
\text { type }\end{array}$} & \multicolumn{3}{|c|}{$\begin{array}{l}\text { Carbon content in different mouza } \\
\qquad\left(\mathrm{t} \mathrm{ha}^{-1}\right)\end{array}$} & \multirow{2}{*}{$\begin{array}{c}\text { Average } \\
\text { organic carbon } \\
\left(\mathrm{t} \mathrm{ha}^{-1}\right)\end{array}$} & \multirow[t]{2}{*}{$\begin{array}{l}\text { Area* } \\
\text { (ha) }\end{array}$} & \multirow{2}{*}{$\begin{array}{c}\text { Carbon } \\
\text { stock } \\
(\mathrm{Gg})\end{array}$} \\
\hline & Naterkona & Khatuary & Meghshimul & & & \\
\hline HL & - & - & $25.40 \pm 0.74$ & 25.40 & 38 & 0.97 \\
\hline MHL & $15.08 \pm 2.60$ & $17.76 \pm 1.70$ & - & 16.42 & 46 & 0.76 \\
\hline MLL & $15.28 \pm 3.96$ & $19.40 \pm 2.79$ & $21.76 \pm 2.16$ & 18.81 & 1025 & 19.28 \\
\hline $\mathrm{LL}$ & $28.44 \pm 0.00$ & - & - & 28.44 & 878 & 24.97 \\
\hline Total & 58.80 & 37.16 & 47.16 & - & 1987 & 45.97 \\
\hline
\end{tabular}

$1 \mathrm{Gg}=10^{9} \mathrm{~g}, *$ SRDI (2009)

Table 9. Organic carbon stocks in different mouza of Akhaura upazila under the agro ecological zone of Northern and Eastern Piedmont Plains in Bangladesh

\begin{tabular}{|c|c|c|c|c|c|c|}
\hline \multirow[t]{2}{*}{$\begin{array}{l}\text { Land } \\
\text { type }\end{array}$} & \multicolumn{3}{|c|}{$\begin{array}{l}\text { Carbon content in different mouza } \\
\qquad\left(\mathrm{t} \mathrm{ha}^{-1}\right)\end{array}$} & \multirow{2}{*}{$\begin{array}{c}\text { Average } \\
\text { organic carbon (t } \\
\left.\text { ha }^{-1}\right)\end{array}$} & \multirow[t]{2}{*}{$\begin{array}{l}\text { Area* } \\
\text { (ha) }\end{array}$} & \multirow[t]{2}{*}{$\begin{array}{c}\text { Carbon stock } \\
(\mathrm{Gg})\end{array}$} \\
\hline & Basudebpur & Noapara & Anandopur & & & \\
\hline HL & $23.56 \pm 0.64$ & - & - & 23.56 & 123 & 29.00 \\
\hline MHL & $24.40 \pm 0.55$ & $27.20 \pm 1.51$ & $28.24 \pm 2.11$ & 26.61 & 2527 & 67.24 \\
\hline MLL & - & - & $24.80 \pm 1.26$ & 24.80 & 590 & 14.63 \\
\hline LL & - & $30.00 \pm 0.44$ & - & 30.00 & 409 & 12.27 \\
\hline Total & 47.96 & 57.20 & 53.04 & - & 3649 & 97.04 \\
\hline
\end{tabular}

$1 \mathrm{Gg}=10^{9} \mathrm{~g}$, * Source: SRDI (1998), HL - High land, MHL - Medium high land, MLL - Medium low land, LL - Low land

In the Northern and Eastern Piedmont Plains of Bangladesh (AEZ 22) the area coverage under high, medium high, medium low and low were 133240.14, 125164.98, 64601.28 and 40375.80 ha, respectively (Table 10). The accumulated organic carbon across $0-20 \mathrm{~cm}$ soil depth under high, medium high, medium low and low land were $24.48,22.52,20.28$ and $28.92 \mathrm{t} \mathrm{ha}^{-1}$, respectively. The carbon stocks in high, medium high, medium low and low land was 3.26, 2.82, 1.31 and $1.17 \mathrm{Tg}$, respectively (Fig. 1). The total area of Northern and Eastern Piedmont Plains was 363382.20 ha and the calculated carbon stock was $8.56 \mathrm{Tg}$. 


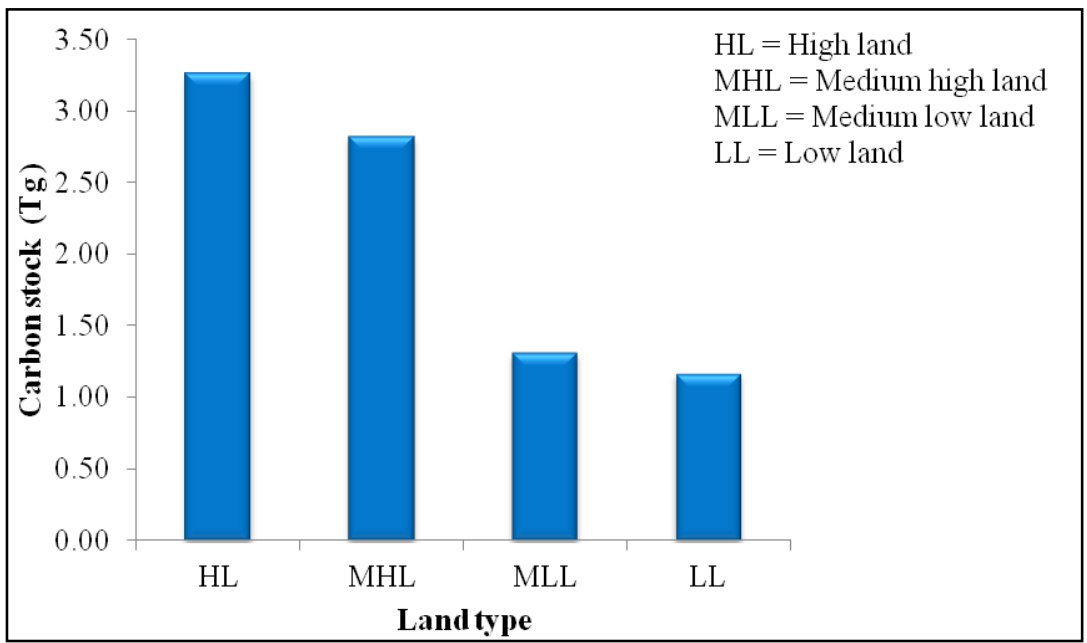

Figure 1. Carbon stocks in soils of different land types in Northern and Eastern Piedmont Plain (AEZ 22)

Table 10. Organic carbon stock in soils of Northern and Eastern Piedmont Plains of Bangladesh

\begin{tabular}{c|c|c}
\hline Land type & Area* $(\mathrm{ha})$ & Organic carbon $\left(\mathrm{t} \mathrm{ha}^{-1}\right)$ \\
\hline HL & 133240.14 & 24.48 \\
MHL & 125164.98 & 22.52 \\
MLL & 64601.28 & 20.28 \\
LL & 40375.80 & 28.92 \\
Total & 363382.20 & - \\
\hline
\end{tabular}

* Source: BARC (2012), HL - High land, MHL - Medium high land, MLL - Medium low land, LL Low land

There is no rating of carbon stock across the soil profile in Bangladesh, however as carbon contents are rated as very low to medium stocks can also be rated as very low to medium. Adoption of resource conservation strategies and best management practices might ensure supply and maintenance of organic matter in soils. It is reported that reduced tillage combined with rotations or cover crops that include deep rooted and high residue producing plants is most effective to enhance soil organic matter in soils (Franzluebbers, 2010, Rahman et al., 2017). Organic matter governs bio-physico-chemical properties of soils and thus maintains and regulates soil quality and nutrient cycling. Organic matters also plays a vital role in the mitigation of global warming and climate change as organic matter can serve both as a source and sink for atmospheric carbon dioxide (Grant et al., 2004). Regular application of available organic materials like rice straw and other crop residues, poultry manure, cowdung, 
household wastes etc. can increase carbon contents in soils which might contribute in developing soil health and ensures sustainability of production systems in the study area.

\section{CONCLUSIONS}

The organic carbon contents in $0-20 \mathrm{~cm}$ depth of high, medium high, medium low and low lands of Purbadhola were 25.40, 16.42, 18.81 and $28.44 \mathrm{t} \mathrm{ha}^{-1}$, respectively, while in case of Akhaura these values were 23.56, 26.61, 24.80 and $30.00 \mathrm{t} \mathrm{ha}^{-1}$, respectively. The total carbon stock in soils of Purbadhola, Akhaura upazila and in the AEZ were $45.97 \mathrm{Gg}, 97.04 \mathrm{Gg}, 8.56 \mathrm{Tg}$, respectively. The soil reaction was very strongly acidic to slightly acidic, organic carbon contents were very low to medium, nitrogen low, phosphorus very low and potassium low to medium. The soils of the Northern and Eastern Piedmont Plains was found slightly acidic to strongly acidic, organic carbon contents were very low to medium, nitrogen low, phosphorus very low and potassium low to medium. The study revealed that carbon stock and nutrient contents in soils of the Northern and Eastern Piedmont Plains were low, which should be increased adopting different soil and crop management practices best suited to the area concerned.

\section{ACKNOWLEDGEMENTS}

The study was conducted under the project 'Carbon sequestration in soils of Bangladesh (ID \# 305)' funded by World Bank, IFAD \& Government of Bangladesh through Bangladesh Agricultural Research Council (BARC), NATP, Phase 1 and implemented by the Department of Soil Science, Bangabandhu Sheikh Mujibur Rahman Agricultural University, Gazipur, Bangladesh.

\section{REFERENCES}

Augusto, L., Ranger, J., Binkley, D., and Rothe, A. (2002). Impact of several common tree species of European temperate forests on soil fertility. Annals of Forest Science, 59, 233-253.

BARC. (2012). Fertilizer recommendation guide. Bangladesh Agricultural Research Council (BARC), Farmgate, Krishi Khamar Sarak, Dhaka 1215.

Barker, D.E., and Surh, N.H. (1982). Atomic absorption and flame emission spectroscopy. In: Methods of Soil Analysis, Part 2, Chemical and Microbiological Properties, A.L. Page, R.H. Miller and D.R. Keeney (eds.), pp. 13-26. American Society of Agronomy and Soil Science Society of America, Madison, Wisconsin, USA

Blake, G.R., and Hartge K.H. (1986). Methods of Soil Analysis, Part I. Physical and Mineralogical Methods. Agronomy Monograph, 9, 363-375.

Bremner, J.M., and Mulvaney, C.S. (1982). Nitrogen. In: Methods of Soil Analysis, Part 2, Chemical and Microbiological Properties, A.L. Page, R.H. Miller and D.R. Keeney (eds.), pp. 595-624. American Society of Agronomy and Soil Science Society of America, Madison, Wisconsin, USA. 
Franzluebbers, A.J. (2010). Achieving soil organic carbon sequestration with conservation agricultural systems in the south eastern United States. Soil Science Society of America Journal. 74(2), 347-357.

Grant, C., Karl, S., and Irvine, B. (2004). Cropping systems impacts on nitrogen availability to plants. Agriculture and Agri-Food Canada, Brandon Research Centre, 1-6.

Hongwei, T., Liuqiang, Z., and Meifu, H. (2003). Soil phosphorus status and crop response in major cropping systems of Guangxi. Better Crops International, 17, 22-25.

Laganiere, J., Angers, D.A., and Pare, D. (2010). Carbon accumulation in agricultural soils after afforestation: a meta-analysis. Global Change Biology, 16, 439-453.

Mclean, E.O. (1982). Soil pH and lime requirement. In: Methods of Soil Analysis, Part 2, Chemical and Microbiological Properties, A.L. Page, R.H. Miller and D.R. Keeney (eds.), pp. 199-224. American Society of Agronomy Inc., Madison, WI, USA.

Olsen, S.R., and Sommers, L.E. (1982). Phosphorus. In: Methods of Soil Analysis, Part 2, Chemical and Microbiological Properties, A.L. Page, R.H. Miller and D.R. Keeney (eds.), pp. 403-430. American Society of Agronomy Inc., Madison, WI, USA.

Rahman, M.M., Biswas, J.C., Maniruzzaman, M., Choudhury, A.K., and Ahmed, F. (2017). Effect of tillage practices and rice straw management on soil environment and carbon dioxide emission. The Agriculturists, 15(1), 127-142.

Rahman, F., Rahman, M.M., Rahman, G.K.M.M., Saleque, M.A., Hossain, A.T.M.S., and Miah, M.G. (2016). Effect of organic and inorganic fertilizers and rice straw on carbon sequestration and soil fertility under rice-rice cropping pattern. Carbon Management, 7(1-2), 41-53.

Rahman, M.M. (2014). Carbon and nitrogen dynamics and carbon sequestration in soils under different residue management. The Agriculturists, 12(2), 48-55.

SRDI. (1988). Soil Resources Development Institute. Land and Soil Resources Utilization Guide, Akhaura Upazila. Ministry of agriculture, Krishi Khamar Sarak, Dhaka-1215.

SRDI. (2009). Soil Resources Development Institute. Land and Soil Resources Utilization Guide, Purbadhola Upazila. Ministry of Agriculture, Krishi Khamar Sarak, Dhaka1215.

Tarnocai, C., Canadell, J.G., Schuur, E.A.G., Kuhry, P., Mazhitova, G., and Zimov, S. (2009). Soil organic carbon pools in the northern circumpolar permafrost region, Global Biogeochemical Cycle, 23, 11.

Vonlutzow, M., and Kogel-Knabner, I. (2009). Temperature sensitivity of soil organic matter decomposition-what do we know? Biology and Fertility of Soils, 46, 1-15. 